\title{
Ecological and pest-management implications of sex differences in scarab landing patterns on grape vines
}

\author{
Mauricio González-Chang ${ }^{\text {Corresp., }}{ }^{1}$ ， Stéphane Boyer ${ }^{2}$ ， Marie-Caroline Lefort ${ }^{1,2}$ ， Jerry Nboyine ${ }^{1}$, Steve D \\ Wratten ${ }^{1}$ \\ ${ }^{1}$ Bio-Protection Research Centre, Lincoln University, Christchurch, Lincoln, New Zealand \\ 2 Environmental and Animal Sciences, Unitec Institute of Technology, Auckland, New Zealand \\ Corresponding Author: Mauricio González-Chang \\ Email address: Mauricio.GonzalezChang@lincolnuni.ac.nz
}

Background Melolonthinae beetles, comprising different white grub species, are a globally-distributed pest group. Their larvae feed on roots of several crop and forestry species, and adults can cause severe defoliation. In New Zealand, the endemic scarab pest Costelytra zealandica (White) causes severe defoliation on different horticultural crops, including grape vines (Vitis vinifera). Understanding flight and landing behaviours of this pest can help inform pest management decisions. Methods Adult beetles were counted and then removed from 96 grape vine plants from 21:30 until 23:00 h, every day from October 26 until December 2, during 2014 and 2015. Also, adults were removed from the grape vine foliage at dusk 5, 10, 15, 20 and 25 min after flight started on 2015. Statistical analyses were performed using generalised linear models with a beta-binomial distribution to analyse proportions and with a negative binomial distribution for beetle abundance.

Results By analysing $C$. zealandica sex ratios during its entire flight season, it is clear that the proportion of males is higher at the beginning of the season, gradually declining towards its end. When adults were successively removed from the grape vines at 5-min intervals after flight activity begun, the mean proportion of males ranged from 6 to 28\%. The male proportion suggests males were attracted to females that had already landed on grape vines, probably through pheromone release. Discussion The seasonal and daily changes in adult $C$. zealandica sex ratio throughout its flight season are presented for the first time. Although seasonal changes in sex ratio have been reported for other melolonthids, changes during their daily flight activity have not been analysed so far. Sexratio changes can have important consequences for the management of this pest species, and possibly for other melolonthids, as it has been previously suggested that $C$. zealandica females land on plants that produce a silhouette against the sky. Therefore, long-term management might evaluate the effect of different plant heights and architecture on female melolonthid landing patterns, with consequences for male distribution, and 
subsequently overall damage within horticultural areas. 


\title{
Ecological and pest-management implications of sex differences in scarab landing patterns on grape vines.
}

Mauricio González-Chang ${ }^{1 *}$, Stéphane Boyer ${ }^{2}$, Marie-Caroline Lefort ${ }^{1,2}$, Jerry Nboyine ${ }^{1}$, Stephen D. Wratten ${ }^{1}$.

1) Bio-Protection Research Centre, Lincoln University, Lincoln 7647, New Zealand.

2) Environmental and Animal Sciences, Unitec Institute of Technology, Auckland 1025, New Zealand.

* corresponding author:

Mauricio González-Chang, Bio-Protection Research Centre, Lincoln University, Lincoln 7647, New Zealand.

Tel: +6402102302975

e-mail: mauriciogonzalezchang@gmail.com

\begin{abstract}
Background

Melolonthinae beetles, comprising different white grub species, are a globally-distributed pest group. Their larvae feed on roots of several crop and forestry species, and adults can cause severe defoliation. In New Zealand, the endemic scarab pest Costelytra zealandica (White) causes severe defoliation on different horticultural crops, including grape vines (Vitis vinifera). Understanding flight and landing behaviours of this pest can help inform pest management decisions.

Methods

Adult beetles were counted and then removed from 96 grape vine plants from 21:30 until 23:00

h, every day from October 26 until December 2, during 2014 and 2015. Also, adults were removed from the grape vine foliage at dusk 5, 10, 15, 20 and 25 min after flight started on 2015. Statistical analyses were performed using generalised linear models with a beta-binomial distribution to analyse proportions and with a negative binomial distribution for beetle abundance.
\end{abstract}

\section{Results}

By analysing $C$. zealandica sex ratios during its entire flight season, it is clear that the proportion of males is higher at the beginning of the season, gradually declining towards its end. When adults were successively removed from the grape vines at 5-min intervals after flight activity begun, the mean proportion of males ranged from 6 to $28 \%$. The male proportion suggests males were attracted to females that had already landed on grape vines, probably through pheromone release.

\section{Discussion}

The seasonal and daily changes in adult $C$. zealandica sex ratio throughout its flight season are presented for the first time. Although seasonal changes in sex ratio have been reported for other 
melolonthids, changes during their daily flight activity have not been analysed so far. Sex-ratio changes can have important consequences for the management of this pest species, and possibly for other melolonthids, as it has been previously suggested that $C$. zealandica females land on plants that produce a silhouette against the sky. Therefore, long-term management might evaluate the effect of different plant heights and architecture on female melolonthid landing patterns, with consequences for male distribution, and subsequently overall damage within horticultural areas.

\section{Introduction}

White grubs (Coleoptera: Scarabaeidae: Melolonthinae) are a widely distributed group of herbivorous insects feeding on a variety of plant hosts around the world (Jackson \& Klein, 2006). Their larvae feed on plant roots, leading to severe damage to commercial crops and pastures (Jackson \& Klein, 2006; Frew et al., 2016), as well as to natural forests and forestry plantations (Švestka, 2006, 2010). Some melolontids do not feed as adults, like Leucopholis lepidophora (Blanchard) (Kalleshwaraswamy et al., 2016) and Phytholaema herrmanni (Germain) (Durán, 1954), while others cause minor plant defoliation. These include Schizonyza ruficollis (F.) (Kulkarni et al., 2007) and Holotrichia spp. (Kulkarni et al., 2009) in India, Hoplia philanthus (Füessly) in Belgium (Ansari et al., 2006), and Phyllophaga cuyabana (Moser) in Brazil (Oliveira \& García, 2003). However, dramatic defoliation can also occur. In Eastern Asia, Ectinohoplia rufipes (Motschulsky) adults can severely defoliate ornamental trees around golf courses, as well as in gardens and parks (Kim et al., 2013). In Central and Western Europe, adult defoliation by Melolontha melolontha (L.) and Melolontha hippocastani (F.) has led to severe defoliation on different horticultural crops, such as grape vines (Vitis vinifera (L.)) and forest trees, respectively (Jackson \& Klein, 2006; Reinecke et al., 2006; Švestka, 2006, 2010). Such defoliation also has been recorded in New Zealand, where Costelytra zealandica (White) attacks several horticultural crops, including tamarillo (Solanum betaceum (Cav.)), avocado (Persea americana (Mill.)), blueberries (Vaccinum corymbosum (L.), strawberries (Fragaria $\mathrm{x}$ ananassa (Duchesne)), kiwifruit (Actinidia chinensis (Planch)), and grape vines (Binfield, 1933; Blank \& Olson, 1982; Blank, Olson \& Bell, 1983; East, Willoughby \& Koller, 1983; East \& Holland, 1984). Sometimes, severe defoliation can occur (Blank, Olson \& Bell, 1983; East, Willoughby \& Koller, 1983; Blank, 1992), leading in some cases to prophylactic application of synthetic insecticides to reduce $C$. zealandica damage. Nowadays, the use of such an approach is discouraged due to the environmental and human health problems related to their use (Reganold \& Wachter, 2016).

The importance of the defoliation produced by melolontids has promoted investigation of their plant colonization patterns, subsequently leading to work on their flying and landing behaviour. In Melolonthinae, after landing on their host plants, females attract males by releasing sex pheromones (Henzell \& Lowe, 1970) or by the release of green leaf volatiles (GLV) produced after feeding on plant foliage (Harari et al., 1994; Reinecke et al., 2002a), or both acting together (Reinecke et al., 2002b; Reinecke et al., 2006). However, in Maladera matrida (Argaman), 
males land on their plant hosts before females. By feeding on their host plant, GLV are released attracting the females to where feeding occurs (Harari, Ben-Yakir \& Rosen, 1994). Observations on C. zealandica flying behaviour have suggested that females land before males on shrubs and trees (Farrell \& Wightman, 1972). After landing, males are attracted to those plants by the female pheromone, identified as phenol (Henzell \& Lowe, 1970). Although the effects of phenol on male attraction are well understood for C. zealandica (Henzell \& Lowe, 1970; Unelius et al., 2008; Marshall et al., 2016), M. melolontha, M. hippocastani (Reinecke et al., 2006), and $P$. cuyabana (Zarbin et al., 2007), there are no studies quantifying adult $C$. zealandica sex ratio at the landing phase of its daily plant colonising activity. In addition, no research has reported the trends in sex ratio throughout the entire $C$. zealandica flight season for any agricultural or natural system. We hypothesized that females arrive on $V$. vinifera before males. Therefore, the aims of this work were: i) to quantify $C$. zealandica sex ratio throughout its seasonal and daily flight period; and ii) to correlate adult abundance with sex ratio through its seasonal and daily flight activity.

\section{Material and Methods}

Study sites

This work was conducted in the Marlborough region of New Zealand. In this area, two commercial vineyards were chosen. One in the Awatere Valley (41 ${ }^{\circ} 44^{\prime} \mathrm{S}$; $\left.173^{\circ} 52^{\prime} \mathrm{E}\right)$ owned by Kono Beverages, and another close to Blenheim city $\left(41^{\circ} 33^{\prime} \mathrm{S}\right.$; $\left.173^{\circ} 55^{\prime} \mathrm{E}\right)$ that belongs to Wither Hills. These locations are situated in homogeneous landscapes generally dominated by conventionally-managed vineyards. To reduce the effect of conventional management practices on the interpretation of the observations described below, organically-managed vineyard blocks (cv. Pinot Noir) were chosen at both sites. The sizes of the blocks were 6.12 and 4.58 ha in the Awatere Valley and Blenheim, respectively. Grape vines were 14 and $15 \mathrm{yr}$ old in the Awatere Valley and Blenheim, respectively. Plant spread along the vine row was $1.8 \mathrm{~m}$ between each other. During the study period, from late October to late November 2014 and 2015, no pesticides or herbicides were applied on those blocks, apart from sulphur, which was applied to control fungal diseases. In New Zealand, organic vineyard areas, including headlands, inter-row and under-vine areas are covered by a mixture of ground covers that mainly comprise ryegrass (Lollium perenne (L.)), white clover (Trifolium repens (L.)), and fescue (Festuca spp.).

\section{Adult C. zealandica sampling}

Sampling was carried out every day during C. zealandica flight season. In the Marlborough area, individuals start flying from the end of October until the end of November (Farrell \& Wightman, 1972). Within the October to November period, adults initiate flight $20 \mathrm{~min}$ after sunset, flying for approximately $26 \mathrm{~min}$ (González-Chang, Unpublished data). During their flight activity, adults land on grape vine foliage and then feed and mate, staying on the grape vines for at least 3 $\mathrm{h}$ (González-Chang, Unpublished data). Based on this landing behaviour, adults were counted and then removed from 96 plants at both study locations from 21:30 until 23:00 h. These plants 
121 had a mean height of $1.5 \mathrm{~m}$, and were consecutively sampled along the vine row over three

122 consecutive rows. Sampling started along the row at the edge of a vineyard block to $50 \mathrm{~m}$ from

123 the edge, sampling 32 plants on each row. The row sampling method was performed at the

124 Awatere Valley during 2014 and 2015 and in Blenheim only on 2015.

125

126

127

128

129

130

131

132

133

134

135

136

137

138

139

140

141

142

143

144

145

146

147

148

149

150

151

152

153

154

155

156

157

158

159

\section{Seasonal sex ratio}

Daily during the 2014 flight season from October $27^{\text {th }}$ until November $30^{\text {th }}$, beetles from the Awatere Valley were collected by hand. During the 2015 flight season, beetle collection started in the Awatere Valley from November $7^{\text {th }}$ until December $1^{\text {st }}$, while in Blenheim from October $26^{\text {th }}$ until December $1^{\text {st }}$. Individual polyethylene bags were used to collect the beetles, so samples were not mixed between days or locations. Using a $50 \mathrm{ml}$ cylindrical plastic container, a subsample was taken from each bag for sex ratio analysis. Within this sub-sample the ratio was analysed by randomly sexing 20 individuals. This procedure was repeated three times for each day. The proportion of males $(\mathrm{M})$ over females $(\mathrm{F})$ for each sampled day was obtained after taking a mean of the three measurements. This proportion was calculated as $M /(M+F)$. Days without flight activity were removed from further sex-ratio analysis. The separation of males from females was carried out using the morphological characteristics proposed by Kain (1972) and Kelsey (1965). Using a stereomicroscope (Carl Zeiss), the distal-ventral section of the abdomen was examined for male characters, including a shallow depression in the centre of the sixth abdominal sternite (Kelsey, 1965), and the presence of parameres through the pygdium (Kain, 1972). Female characters included the presence of colleterial glands, as two spherical dots in the fifth sternite, and two genital sclerites situated at each side of the vulva (Kain, 1972).

\section{Adult C. zealandica removal to determine daily sex-ratio patterns}

To investigate the dynamics of sex-ratio changes on grape vine foliage during the flight season, adult beetles were successively removed from the grape vines at different periods during 2015 . At both sites, adults were removed from the grape vine foliage at dusk at 5, 10, 15, 20 and 25 min after flight started. One plant at the edge of each vineyard block at both locations was used for this experiment. This plant was not included in the 96 plants used in the seasonal sex-ratio determination explained above. Adults were visually counted on the selected grape vine and then removed by hand at each time period. When the number of adults collected exceeded 60,20 individuals were sub-sampled three times from those samples. The mean of the sub-sampled was used for further statistical analyses. This daily sequential adult removal was performed from November 2 to 28 and November 14 to 28 at Blenheim and the Awatere Valley, respectively. Days without flight activity, because of adverse weather, were removed from further sex-ratio analysis. The mean proportion of males and total adult numbers at each sampling day at each time interval were considered as replicates.

\section{Statistical analyses}


160

161

162

163

164

165

166

167

168

169

170

171

172

173

174

175

176

177

178

179

180

181

182

183

184

185

186

187

188

189

190

191

192

193

194

195

196

197

198

The proportions obtained for each day during the sampling season, and those calculated at each evaluated time period, were analysed using a generalised linear model (GLM), with a betabinomial distribution and "logit" as the link function (Cribari-Neto \& Zeileis, 2010). It has been previously suggested that the beta regression approach is inherently heteroscedastic and easily accommodates asymmetries typically found in rates and proportions (Cribari-Neto \& Zeileis, 2010; Grün, Kosmidis \& Zeileis, 2012). Beta-binomial GLMs were calculated with the R package "betareg” (Cribari-Neto \& Zeileis, 2010). Spearman's rank correlation was used to assess the correlation between adult abundance and sex ratio through the flight season (Crawley, 2007). The same analysis was used to evaluate the correlation between adult abundance and the sex ratio at each time period studied. Differences in adult abundance between periods were analysed using Tukey's multiple contrasts post-hoc analysis (Venables \& Ripley, 2002) after fitting a GLM with a negative binomial distribution and a logarithmic link function at each sampling site. Negative binomial GLM and Tukey's tests were performed using the R packages "MASS" and "multcomp", respectively. All statistical analyses were performed using the statistical software R v.3.2.5 (R Core Team, 2016).

\section{Results}

Seasonal sex ratio

In the Awatere Valley in 2014, a total of 36,369 adults were sampled, while in 2015 only 6,111 were collected. During 2015 in Blenheim, 14,731 adults were collected. Sex-ratio was not statistically correlated with beetle abundance through the flight season in the Awatere Valley during $2014(\varphi=0.02 ; p=0.92)$ nor in $2015(\varphi=-0.35 ; p=0.12)$. However, at the Blenheim site, this correlation was positive and significant $(\varphi=0.51 ; p<0.01)$. In the Awatere Valley the proportion of males decreased through time during 2014 (slope $=-0.08 ; \mathrm{z}=-4.8 ; p<0.001$ ) and in 2015 (slope $=-0.02 ; \mathrm{z}=-2.6 ; p<0.01$ ). A similar result was observed in Blenheim during 2015 (slope=$0.03 ; \mathrm{z}=-4 ; p<0.001)$. Seasonal sex-ratio results are shown in Figs. 1-3.

Adult C. zealandica removal to determine daily sex-ratio patterns

When adults were removed from the grape vine foliage every 5 min after flight activity started, the proportion of males increased through the 5 to $25 \mathrm{~min}$ time interval at Blenheim (slope $=0.06$; $\mathrm{z}=2.12 ; p<0.05$ ), but not at the Awatere Valley (slope $=0.001 ; \mathrm{z}=0.03 ; p=0.98$ ) (Fig. 4). Tukey contrasts showed that adult numbers significantly increased between 10 and 15 min after flight occurred at both sites, and then decreased to initial levels between 20 and 25 min after it started (Fig. 5). In the Awatere Valley, flight activity completely ceased $25 \mathrm{~min}$ after begun, while in Blenheim it stopped after $30 \mathrm{~min}$. No correlation was found between adult abundance and the sex-ratio during each time period evaluated at Blenheim $(\varphi=-0.1 ; p=0.87)$ or in the Awatere Valley $(\varphi=-0.8 ; p=0.2)$.

\section{Discussion}


199

200

201

202

203

204

205

206

207

208

209

210

211

212

213

214

215

216

217

218

219

220

221

222

223

224

225

226

227

228

229

230

231

232

233

234

235

236

237

In this work, seasonal and daily changes in adult $C$. zealandica sex-ratio throughout its flight season are presented for the first time. The proportion of males significantly decreased towards the end of the season at both studied locations. However, when adults were removed from the grape vine foliage at several time periods during the same day, trends in the sex-ratio differed between the two locations. These results are discussed in terms of this insect's behaviour. The implications of these results on sustainable C. zealandica control in vineyards also are discussed.

\section{Seasonal sex-ratio trend}

A widely-accepted sex-ratio theory based on natural selection proposed by R.A. Fisher, suggests that sex-ratio is equilibrated on a 1:1 proportion to promote species survival (Fisher, 1930). However, many species do not follow the 1:1 theoretical proportion as they respond to their changing local environmental conditions (Hamilton, 1967). In Melolonthinae sex-ratio though their flight season can be female-biased (Méndez-Aguilar et al., 2005; Kalleshwaraswamy et al., 2016), male-biased (Ansari et al., 2006; Švestka, 2006, 2010) or at a 1:1 ratio (Harari, Ben-Yakir \& Rosen, 1994; Méndez-Aguilar et al., 2005). However, it is worthwhile noting that sex-ratio can vary between those proportions every day during the flight season (Švestka, 2006, 2010; Kalleshwaraswamy et al., 2016), as shown in this study (Figs. 1-3). In this work, seasonal sexratio varied between years and locations, being male-biased (64\% males) and female-biased (47\% males), in the Awatere Valley in 2014 and 2015, respectively. In Blenheim, the seasonal sex-ratio was 1:1 (50\% males). The sex-ratio differences between sites in this study highlights the temporal and spatial variability of melolontid sex-ratio, which might be determined by environmental conditions (Sánchez, 2008; Gempe \& Beye, 2011). Previous studies suggested that C. zealandica males appear seasonally before females do (Kelsey, 1951; Pottinger, 1968; Farrell \& Wightman, 1972). Early male appearance might have important evolutionary consequences for the survival of $C$. zealandica because as soon as the females emerge, males are already present for mating (Kelsey, 1951; Durán, 1954; Harari, Ben-Yakir \& Rosen, 1994; Kalleshwaraswamy et al., 2016). The evolutionary advantage of early male emergence is in agreement with the results presented in this work, as a higher proportion of males were found at the beginning of the flight season at both studied years and locations. The reduction in male numbers through time might be associated with a reduction in female pheromone production towards the end of the flight season, as pheromone effects on male attractiveness have been well studied in C. zealandica (Henzell, 1970; Unelius et al., 2008; Marshall et al., 2016). Recently, it has been suggested that phenol, the main sex pheromone in C. zealandica (Henzell, 1970), is produced by a mutualistic bacterium Morganella morganii (Brenner) in its colleterial gland, which is biosynthesized from the amino acid tyrosine (Marshall et al., 2016). In general, insect protein synthesis decreases with aging (Levenbook, 1986), and tyrosine in particular has been shown to decrease with age in other insects like Bombyx mori (L.) (Lepidoptera: Bombycidae) (Osanai \& Kikuta, 1981). Considering that the C. zealandica flight season lasted for around 4 wk, from late October to late November at the studied vineyards, females that landed on the 
238

239

240

241

242

243

244

245

246

247

248

249

250

251

252

253

254

255

256

257

258

259

260

261

262

263

264

265

266

267

268

269

270

271

272

273

274

275

276

277

grape vine foliage at the end of that period might already have ceased to synthesize their pheromone due to aging, reducing the number of males attracted to them.

In the Awatere Valley, no correlation was found between adult numbers throughout the flight season and changes in the sex-ratio. However, in Blenheim, the correlation was positive and significant. A positive correlation suggests that an increase in adult numbers is due an increase in the number of males, because in the Awatere Valley 2014 flight season, 63\% of the sampled adults at their November 14 peak in abundance (6,968 individuals) were males. Conversely, at the same location during 2015, only $37 \%$ of the adults were males at their November 19 peak (1,039 individuals). In Blenheim, $55 \%$ of them were males at their November 6 peak $(1,966$ individuals).

\section{Adult removal and daily sex-ratio trends}

Costelytra zealandica flight activity has been divided in two phases (Kelsey, 1951; Pottinger, 1968; Farrell \& Wightman, 1972). Firstly, males emerge from the ground and hover over the grass. When females emerge, they climb to the top of a grass blade and release their sex pheromone to attract males. Once mating has occurred, females return to the ground to lay eggs. Secondly, females fly from the grass, searching for silhouettes in the sky, landing on trees, hedgerows and shrubs (Farrell \& Wightman, 1972). After landing occurs, pheromones are released, attracting males from the surrounding areas again. Then, males and females drop to the ground and females again lay eggs, although in fewer numbers compared to their first ovisposition made close to their initial emergence sites (Farrell \& Wightman, 1972). The results presented in this work are in agreement with the colonization sex-driven dynamics for the second flight phase observed during 1970s (Farrel \& Wightmann, 1972), in which females land first on the vegetation; as the proportion of males found when adults were removed from the grape vines never exceed $28 \%$. In fact, 10-min after flight begun, only 9 and $18 \%$ of the removed adults were males at the Awatere Valley and Blenheim, respectively. Remarkably, an identical two-phase flight behaviour has been described before for Phyllopertha horticola (L.) (Coleoptera: Rutelinae) (Schneider, 1962) and for P. herrmanni (Durán, 1954). Also, similar landing behaviour where female melolontids arrive before males on plant foliage has been reported for M. melolontha, M. hippocastani (Reinecke et al., 2002a) and P. cuyabana (Oliveira \& García, 2003). In the Awatere Valley (2015), the proportion of males did not change throughout their daily flight activity, which lasted for 25 min. However, in Blenheim (2015) male proportion increased throughout their daily flight period, which totally ceased $30 \mathrm{~min}$ after flight begun. These differences in adult abundance and flight length at dusk could be related to the two-fold increase in adult numbers found in Blenheim compared to the Awatere Valley.

\section{Female behaviour and plant silhouettes}

Considering that males are attracted to females that have already landed on their host plant, through pheromone communication (Henzell \& Lowe, 1970) and/or plant volatiles (Reinecke et al., 2002a), the mechanisms by which females locate host plants have relevance to pest 
278

279

280

281

282

283

284

285

286

287

288

289

290

291

292

293

294

295

296

297

298

299

300

301

302

303

304

305

306

307

308

309

310

311

312

313

314

315

316

317

management. Different authors have proposed that female host finding in Melolonthinae is through the visual recognition of the tallest plant silhouettes in the sky (Durán, 1954; Schneider, 1962; Farrell \& Wightman, 1972; Oliveira \& García, 2003). A study in Brazil showed that $P$. cuyabana females preferred tall soybean and corn plants for landing and mating (García, Oliveira $\&$ de Oliveira, 2003). Recent work suggests that plant location by $C$. zealandica females might be mediated by the contrast that plant silhouettes produce in the sky (González-Chang, Unpublished data). Males also might use visual cues in the sky for orientation at some extent, but more research is needed, as no evidence for the latter exist so far. Thus, additional research investigating the addition of tall plant species at the edge of crops could have management values, especially if the tall plants can divert females from landing further into the crop area, and in turn, deterring males from the crop.

\section{Implications for sustainable C. zealandica management in vineyards}

Recently, it has been suggested that a "push-pull" strategy (Khan et al., 2011) might contribute to the control of white grub populations (Dynastinae, Rutelinae, Melolonthinae) around the world (Frew et al., 2016). In the context of C. zealandica pest control in grape vines, it seems straightforward to use the sex attractant pheromone (phenol) to "pull" the adults away from the grape vines. Phenol, combined with another management intervention which "pushes" the adults away, as recently shown when crushed mussel shells were applied on the under-vine vineyard areas (González-Chang, Unpublished data), might arise as a novel variant on the "push-pull" approach to control this New Zealand pest in several horticultural crops. However, the use of phenol in such a way has some shortcomings. Although phenol was identified as the pheromone for C. zealandica more than 40 years ago (Henzell \& Lowe, 1970), it has not been widely used to control this pest due constraints in trap design that led to low capture efficiency (Unelius et al., 2008). Another negative factor of using phenol is its high toxicity for humans (Shadnia \& Wright, 2008; Unelius et al., 2008). Instead, if females can be attracted to a host plant outside the crop, the overall numbers of adult $C$. zealandica landing on the crop could be reduced, along with subsequent reduction in plant damage (González-Chang, Unpublished data). The mechanisms behind female $C$. zealandica host location remain unknown with literature only suggesting that females might locate host plants by their contrast against the sky at dusk (Farrell \& Wightman, 1972). Despite those assumptions, it cannot be ignored that females can also be attracted to different floral plant volatiles, as demonstrated for P. horticola (Ruther, 2004). Furthermore, the potential contribution of GLV, released from adult feeding (Reinecke et al., 2002b), may influence seasonal C. zealandica peak activity and abundance, because peak damage coincides with peak flight activity in the middle of the flight season (East et al., 1983). In this work, the peak of abundance was registered during the middle of the flight season. Thus, the chemical ecology underlying $C$. zealandica reproductive behaviour needs further investigation. Another approach could evaluate the contribution of native New Zealand vegetation within or outside the vineyard (Shields et al., 2016), as non-crop vegetation could provide visual silhouettes and organic volatiles to further attract males or females. Although the 
318

319

320

321

322

323

324

325

326

327

328

329

330

331

332

333

334

335

336

337

338

339

340

341

342

343

344

345

346

347

348

349

350

351

352

353

354

355

356

357

establishment and growth of those native plants in horticultural areas will take time, native plants could contribute to a long-term sustainable $C$. zealandica pest management strategy, with potential enhancement of local functional biodiversity and biological conservation that need to be further addressed (Isaacs et al., 2009).

\section{Conclusions}

The proportion of $C$. zealandica males landing on the grape vine foliage decreased throughout the flight season during 2014 and 2015 at two New Zealand locations. Blenheim (2015) was the only site where increases in sex-ratio (male-biased) were correlated with increases in overall adult abundance. The sex-ratio correlation with adult abundance might be related to spatial and temporal landscape variations in sex-ratio between Blenheim and the Awatere Valley, although landscape factors were not measured here. When adults were removed daily from the grape vines at several time periods after their flight activity begun, a female-biased sex-ratio was recorded. The female-based sex-ratio suggests that females land on the plant foliage before males, subsequently attracting them by the release of their phenol sex pheromone. The grape vine colonization sex-driven dynamics during adult $C$. zealandica flight activity presented in this work might contribute to management useful in reducing the damage of this endemic New Zealand pest on several horticultural crops, and eventually in other scarabaeids with similar flight behaviour around the world.

\section{Acknowledgements}

We gratefully acknowledge the assistance provided by Coralline Houise, Estelle Postic, Héléna Minet and Lucie Archard.

\section{References}

Ansari MA, Casteels H, Tirry L, Moens M. 2006. Biology of Hoplia philanthus (Col., Scarabaeidae, Melolonthinae): A new and severe pest in Belgian turf. Environmental Entomology 35:1500-1507. DOI: 10.1603/0046-225X(2006)35[1500:BOHPCS]2.0.CO;2.

Binfield RE. 1933. Grass grub in strawberry beds. New Zealand Journal of Agriculture 47:175.

Blank RH, Olson MH. 1982. Grass grub adults defoliate tamarillos in Northland. Proceedings of the 35th New Zealand Weed and Pest Control Conference:27-31.

Blank RH, Olson MH, Bell DS. 1983. Screening insecticides to protect tamarillo against grass grub adults. Proceedings of the 36th New Zealand Weed and Pest Control Conference:111115.

Blank RH. 1992. Research on pastoral and horticultural pest control in Northland helps to avoid problems with insecticide use. New Zealand Entomologist 15:76-80.

Crawley M. 2007. The R book. Chichester: John Wiley and Sons.

Cribari-Neto F, Zeileis A. 2010. Beta regression in R. Journal of Statistical Software 34:1-24.

Durán L. 1954. La biología del Phytoloema herrmanni Germ. y mención de otros escarabeidos perjudiciales a la agricultura en las provincias australes de Chile. Revista Chilena de 
Historia Natural 54:5-20.

East R, Holland PT. 1984. Control of grass grub in blueberries. Proceedings of the New Zealand Weed and Pest Control Conference 37:228-230.

East R, Willoughby BE, Koller MS. 1983. Defoliation by grass grub beetles in Waikato orchards. Proceedings of the 36th New Zealand Weed and Pest Control Conference 36:151155.

Farrell JAK, Wightman JA. 1972. Observations on flight and feeding activity of adult Costelytra zealandica (White) (Col.,Scarabaeidae) in Nelson province. New Zealand Journal of Agricultural Research 15:893-903. DOI: 10.1080/00288233.1972.10421644.

Fisher RA. 1930. The genetical theory of natural selection. London, UK: Oxford University Press. (p. 143) DOI: 10.1038/158453a0.

Frew A, Barnett K, Nielsen UN, Riegler M, Johnson SN. 2016. Belowground ecology of scarabs feeding on grass roots: Current knowledge and future directions for management in Australasia. Frontiers in Plant Science 7:321. DOI: 10.3389/fpls.2016.00321.

García MA, Oliveira LJ, de Oliveira MCN. 2003. Aggregation behavior of Phyllophaga cuyabana (Moser) (Coleoptera: Melolonthidae): Relationships between sites chosen for mating and offspring distribution. Neotropical Entomology 32:537-542.

Gempe T, Beye M. 2011. Function and evolution of sex determination mechanisms, genes and pathways in insects. BioEssays 33:52-60. DOI: 10.1002/bies.201000043.

Grün B, Kosmidis I, Zeileis A. 2012. Extended beta regression in R: Shaken, stirred, mixed, and partitioned. Journal of Statistical Software 48:1-25.

Hamilton WD. 1967. Extraordinary sex ratios. Science 156:477-488.

Harari AR, Ben-Yakir D, Rosen D. 1994. Mechanism of aggregation behavior in Maladera matrida Argaman (Coleoptera: Scarabaeidae). Journal of Chemical Ecology 20:361-371. DOI: 10.1007/BF02064443.

Henzell RF. 1970. Phenol, an attractant for the male grass grub beetle (Costelytra zealandica (White)) (Scarahaeidae: Coleoptera). New Zealand Journal of Agricultural Research 13:294-296. DOI: 10.1080/00288233.1970.10425402.

Henzell RF, Lowe MD. 1970. Sex attractant of the grass grub beetle. Science 168:1005-1006. Isaacs R, Tuell J, Fiedler A, Gardiner M, Landis D. 2009. Maximizing arthropod-mediated ecosystem services in agricultural landscapes: The role of native plants. Frontiers in Ecology and the Environment 7:196-203.

Jackson TA, Klein MG. 2006. Scarabs as pests: A continuing problem. Coleopterists Society Monograph 5:102-119.

Kain WM. 1972. Identification of the sexes in Costelytra zealandica (Coleoptera: Scarabaeidae). New Zealand Journal of Science 15:85-87.

Kalleshwaraswamy CM, Adarsha SK, Naveena NL, Sharanabasappa. 2016. Adult emergence pattern and utilization of females as attractants for trapping males of white grubs, Leucopholis lepidophora (Coleoptera: Scarabaeidae), infesting areca nut in India. Journal of Asia-Pacific Entomology 19:15-22. DOI: 10.1016/j.aspen.2015.11.004. 
398

399

400

401

402

403

404

405

406

407

408

409

410

411

412

413

414

415

416

417

418

419

420

421

422

423

424

425

426

427

428

429

430

431

432

433

434

435

436

437

Kelsey JM. 1951. Grass-grub and grass caterpillar control. New Zealand Journal of Agriculture $83: 113-122$.

Kelsey JM. 1965. Note on morphological differences between sexes of adult Costelytra zealandica (White). New Zealand Journal of Science 8:173.

Khan Z, Midega C, Pittchar J, Pickett J, Bruce T. 2011. Push-pull technology: a conservation agriculture approach for integrated management of insect pests, weeds and soil health in Africa. International Journal of Agricultural Sustainability 9:162-170. DOI: 10.3763/ijas.2010.0558.

Kim JJ, Choo HY, Jung YH, Lee SM, Park J-J, Lee DW. 2013. Life history and population dynamics of Ectinohoplia rufipes (Coleoptera: Scarabaeidae) on Korean golf courses. Journal of Asia-Pacific Entomology 16:379-384. DOI: 10.1016/j.aspen.2013.04.004.

Kulkarni N, Chandra K, Wagh PN, Joshi KC, Singh RB. 2007. Incidence and management of white grub, Schizonycha ruficollis on seedlings of teak (Tectona grandis Linn. f.). Insect Science 14:411-418. DOI: 10.1111/j.1744-7917.2007.00168.x.

Kulkarni N, Paunikar S, Joshi KC, Rogers J. 2009. White grubs, Holotrichia rustica and Holotrichia mucida (Coleoptera: Scarabaeidae) as pests of teak (Tectona grandis L. f.) seedlings. Insect Science 16:519-525. DOI: 10.1111/j.1744-7917.2009.01289.x.

Levenbook L. 1986. Protein synthesis in relation to insect aging: An overview. In: Collatz K-G, Sohal RS eds. Insect Aging. Strategies and mechanisms. Springer-Verlag, 200-206.

Marshall DG, Jackson TA, Unelius CR, Wee SL, Young SD, Townsend RJ, Suckling DM. 2016. Morganella morganii bacteria produces phenol as the sex pheromone of the New Zealand grass grub from tyrosine in the colleterial gland. The Science of Nature 103:59. DOI: 10.1007/s00114-016-1380-1.

Méndez-Aguilar M de J, Castro-Ramírez A, Alvarado R, Pacheco-Flores C, Ramírez-Salinas C. 2005. Eficacia de dos tipos de recolecta para registrar la diversidad de melolóntidos nocturnos (Coleoptera: Scarabaeoidea). Acta Zoológica Mexicana 21:109-124.

Oliveira LJ, García MA. 2003. Flight, feeding and reproductive behavior of Phyllophaga cuyabana (Moser) (Coleoptera: Melolonthidae) adults. Pesquisa Agropecuaria Brasileira 38:179-186.

Osanai M, Kikuta S. 1981. Age-related changes in amino acid pool sizes in the adult silkworm, Bombyx mori. Experimental Gerontology 16:445-459.

Pottinger RP. 1968. Comments on the ecology of grass grub and porina caterpillar. Proceedings of New Zealand Grassland Association 30:102-112.

R Core Team, 2016. R: A language and environment for statistical computing. R Foundation for Statistical Computing, Vienna, Austria.

Reganold JP, Wachter JM. 2016. Organic agriculture in the twenty-first century. Nature Plants 2:15221. DOI: 10.1038/NPLANTS.2015.221.

Reinecke A, Ruther J, Hilker M. 2002a. The scent of food and defence: Green leaf volatiles and toluquinone as sex attractant mediate mate finding in the European cockchafer Melolontha melolontha. Ecology Letters 5:257-263. DOI: 10.1046/j.1461-0248.2002.00318.x. 
438

439

440

441

442

443

444

445

446

447

448

449

450

451

452

453

454

455

456

457

458

459

460

461

462

463

464

465

466

467

468

469

470

471

472

473

474

475

476

477

Reinecke A, Ruther J, Tolasch T, Francke W, Hilker M. 2002b. Alcoholism in cockchafers: Orientation of male Melolontha melolontha towards green leaf alcohols. Naturwissenschaften 89:265-269. DOI: 10.1007/s00114-002-0314-2.

Reinecke A, Ruther J, Mayer CJ, Hilker M. 2006. Optimized trap lure for male Melolontha cockchafers. Journal of Applied Entomology 130:171-176. DOI: 10.1111/j.14390418.2006.01041.x.

Ruther J. 2004. Male-biassed response of garden chafer, Phyllopertha horticola L., to leaf alcohol and attraction of both sexes to floral plant volatiles. Chemoecology 14:187-192. DOI: $10.1007 / \mathrm{s} 00049-004-0271-7$.

Sánchez L. 2008. Sex-determining mechanisms in insects. The International Journal of Developmental Biology 52:837-856. DOI: 10.1387/ijdb.0723961s.

Schneider F. 1962. Dispersal and migration. Annual Review of Entomology 7:223-242.

Shadnia H, Wright JS. 2008. Understanding the toxicity of phenols: Using quantitative structureactivity relationship and enthalpy changes to discriminate between possible mechanisms. Chemical Research in Toxicology 21:1197-1204. DOI: 10.1021/tx800058r.

Shields M, Tompkins J-M, Saville DJ, Meurk CD, Wratten S. 2016. Potential ecosystem service delivery by endemic plants in New Zealand vineyards: successes and prospects. PeerJ 4:e2042.

Švestka M. 2006. Distribution of tribes of cockchafers of the genus Melolontha in forests of the Czech Republic and the dependence of their swarming on temperature. Journal of Forest Science:520-530.

Švestka M. 2010. Changes in the abundance of Melolontha hippocastani Fabr. and Melolontha melolontha (L.) (Coleoptera: Scarabeidae) in the Czech Republic in the period 2003-2009. Journal of Forest Science 56:417-428.

Unelius CR, Townsend RJ, Mundy DC, Manning LM, Jackson TA, Suckling DM. 2008. Comparisons of traps and lures for monitoring grass grub, Costelytra zealandica. New Zealand Plant Protection 61:215-221.

Venables WN, Ripley BD. 2002. Modern applied statistics with S. New York: Springer-Verlag. DOI: 10.1198/tech.2003.s33.

Zarbin PHG, Leal WS, Ávila CJ, Oliveira LJ. 2007. Identification of the sex pheromone of Phyllophaga cuyabana (Coleoptera: Melolonthidae). Tetrahedron Letters 48:1991-1992. DOI: $10.1016 /$ j.tetlet.2007.01.075. 
479

480

481

482

483

484

485

486

487

488

489

490

491

492 


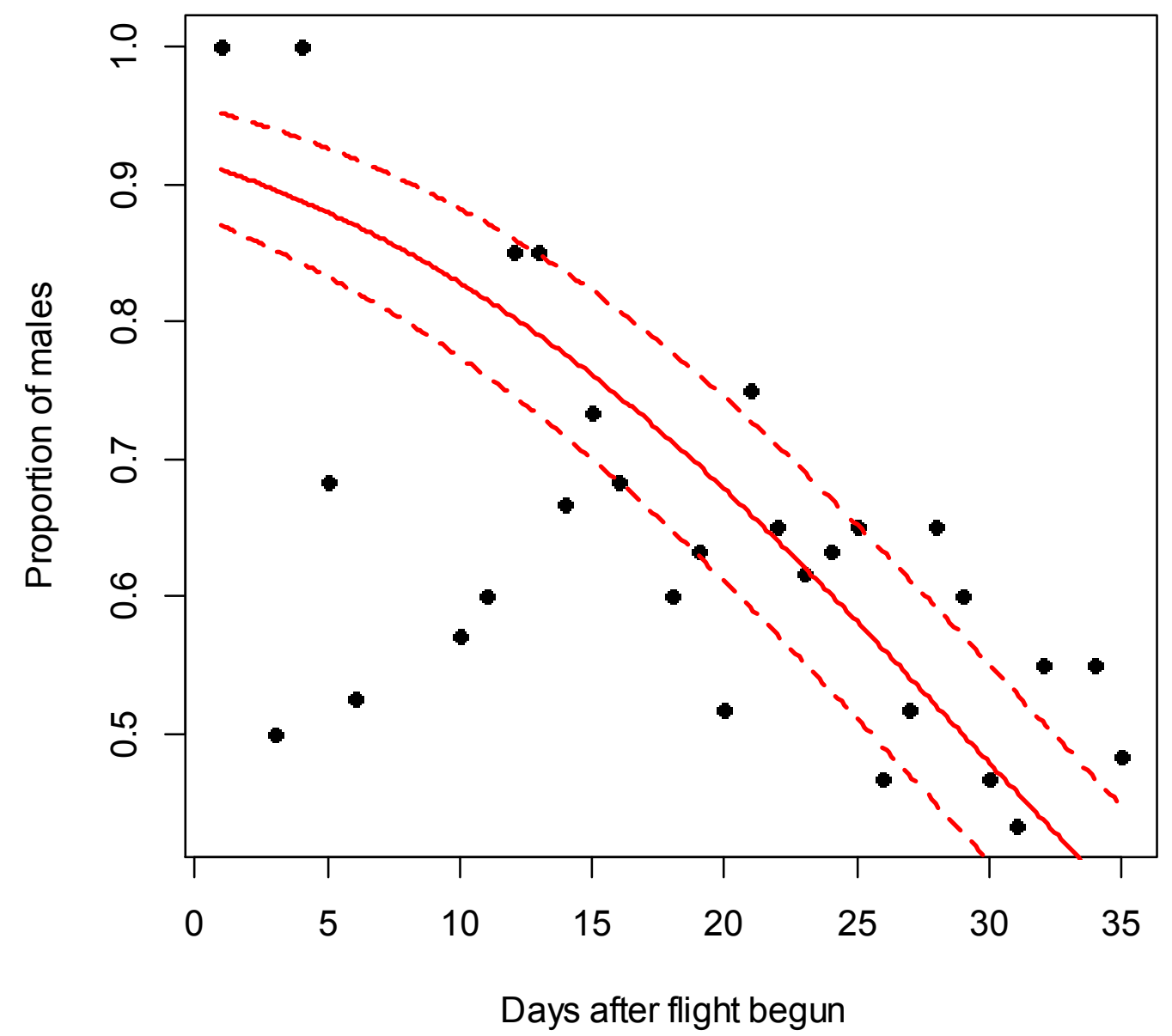

493

494

495

496

497

498

499

Figure 1 Costelytra zealandica sex-ratio (proportion of males) on $35 \mathrm{~d}$ after its flight begun, from October $27^{\text {th }}$ to November $30^{\text {th }}$ at the Awatere Valley in 2014. The beta-binomial GLM (solid line) adjusted to each proportion during the flight season is presented with its respective confidence intervals (dashed lines). The proportion of males is reduced through time (slope $=-$ $0.08 ; \mathrm{z}=-4.8 ; p<0.001$ ). Days without flight activity during the season were removed from this analysis. 


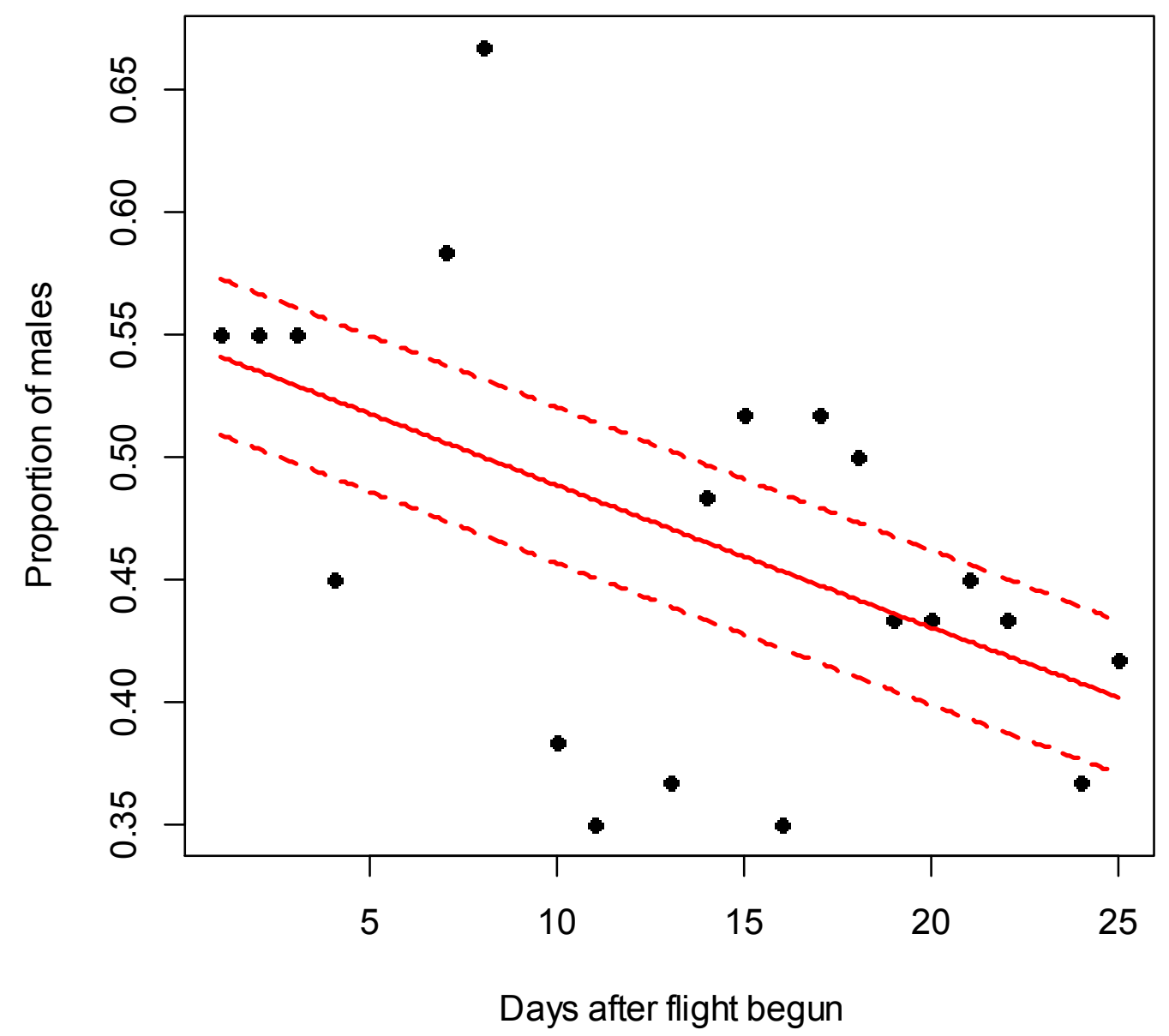

500

501 Figure 2 Costelytra zealandica sex-ratio (proportion of males) on $25 \mathrm{~d}$ after its flight begun, 502 from November $7^{\text {th }}$ to December $1^{\text {st }}$ at the Awatere Valley in 2015 . The beta-binomial GLM 503 (solid line) adjusted to each proportion during the flight season is presented with its respective 504 confidence intervals (dashed lines). The proportion of males is reduced through time (slope=$5050.02 ; \mathrm{z}=-2.6 ; p<0.01$ ). Days without flight activity during the season were removed from this 506 analysis. 


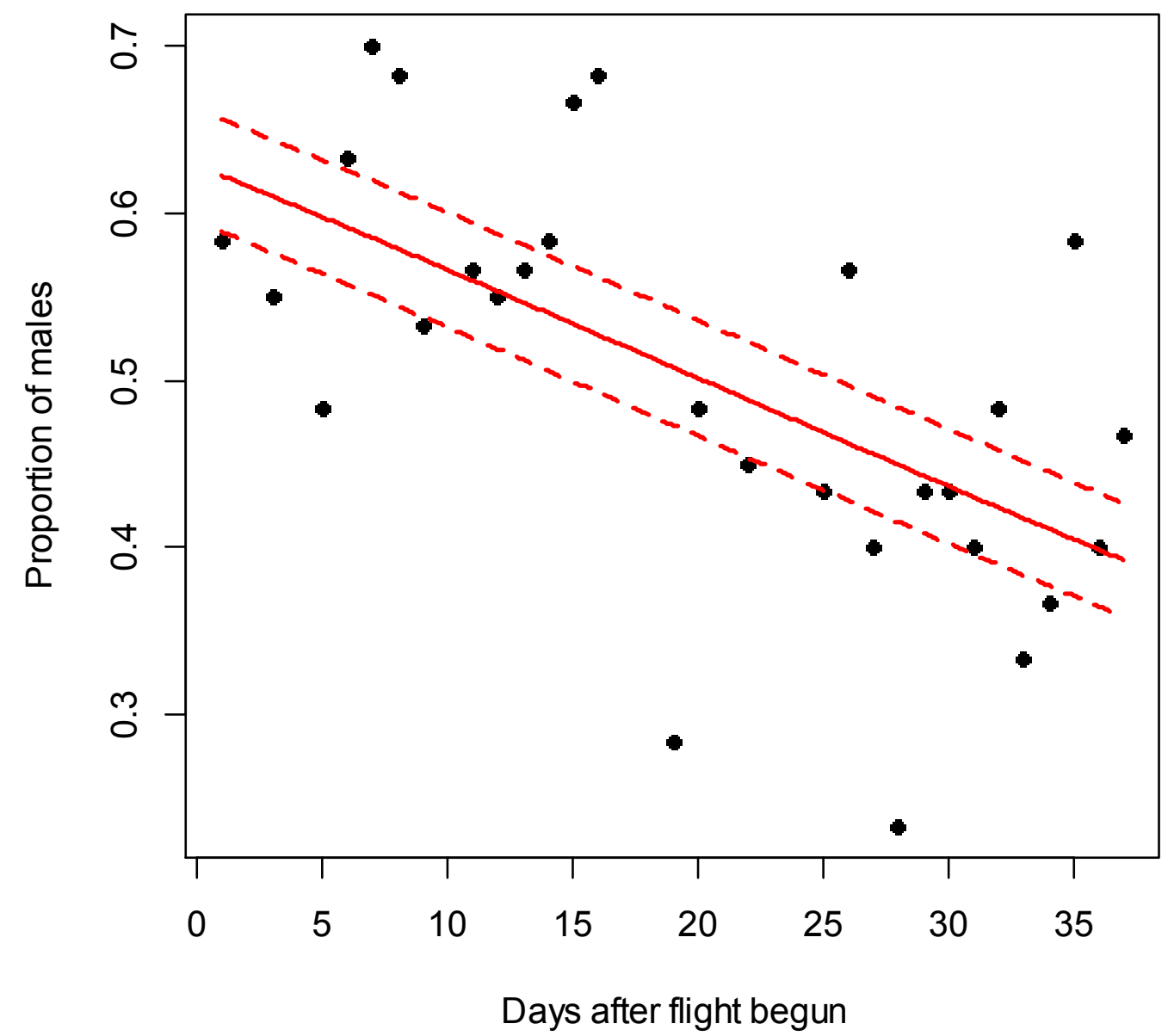

507

508 Figure 3 Costelytra zealandica sex-ratio (proportion of males) on $37 \mathrm{~d}$ after its flight begun, 509 from October $26^{\text {th }}$ to December $1^{\text {st }}$ close to Blenheim city in 2015. The beta-binomial GLM 510 (solid line) adjusted to each proportion during the flight season is presented with its respective 511 confidence intervals (dashed lines). The proportion of males is reduced through time (slope=$5120.03 ; \mathrm{z}=-4 ; p<0.001$ ). Days without flight activity during the season were removed from this 513 analysis 

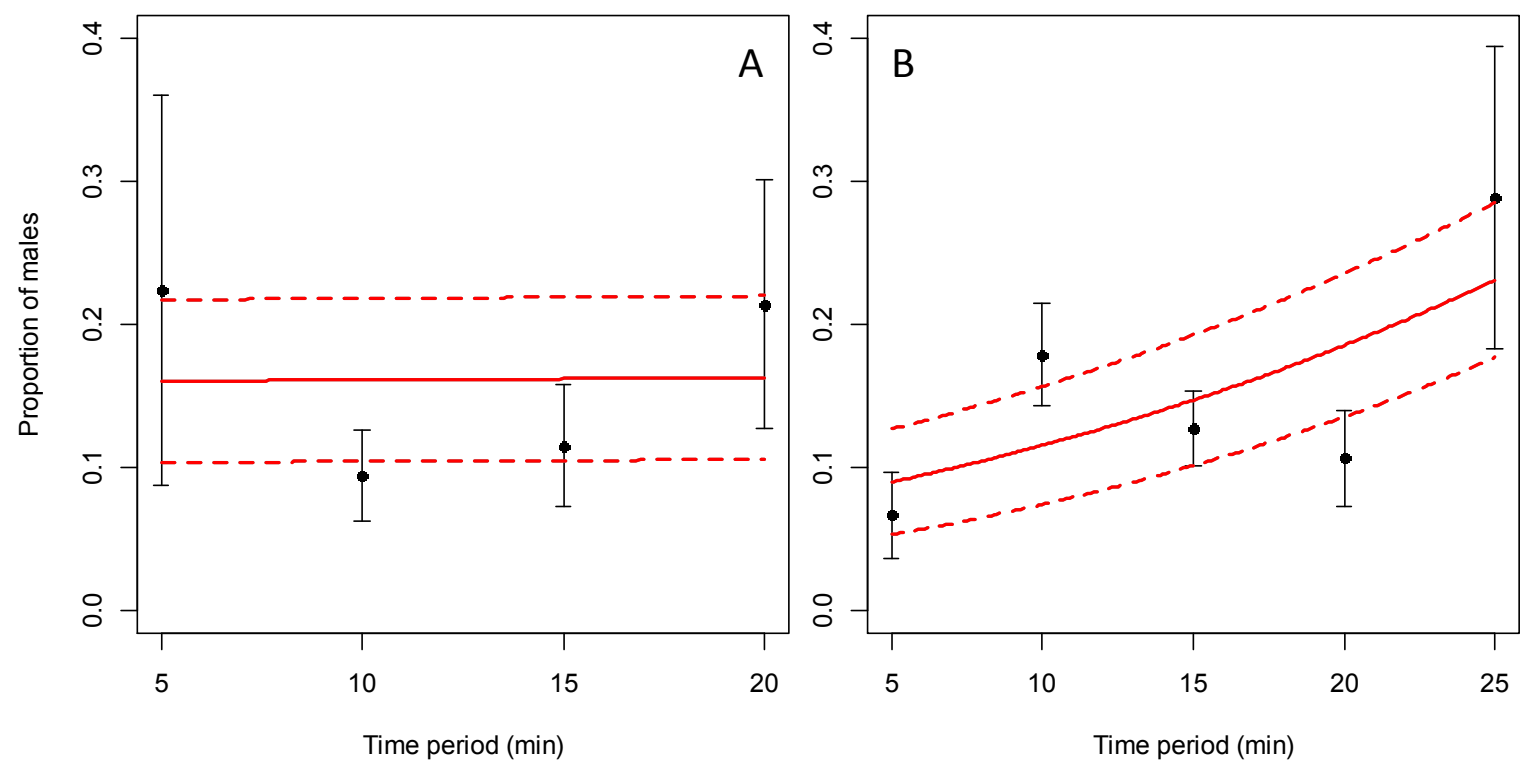

514

Figure 4 Proportion of $C$. zealandica males, after adult removal from a single grape vine plant at

5165 min periods after daily flight activity begun, at the Awatere Valley (A) and Blenheim (B). The

517 beta-binomial GLM (solid line) adjusted to each proportion during those time periods is

518 presented with its respective confidence intervals (dashed lines). In the Awatere Valley (right),

519 male proportion did not change during $C$. zealandica daily flight activity (

$520 p=0.98$ ), but in Blenheim (left), it increased through the daily flight time period (slope $=0.06$;

$521 \mathrm{z}=2.12 ; p<0.05)$. Error bars are two-standard errors. 


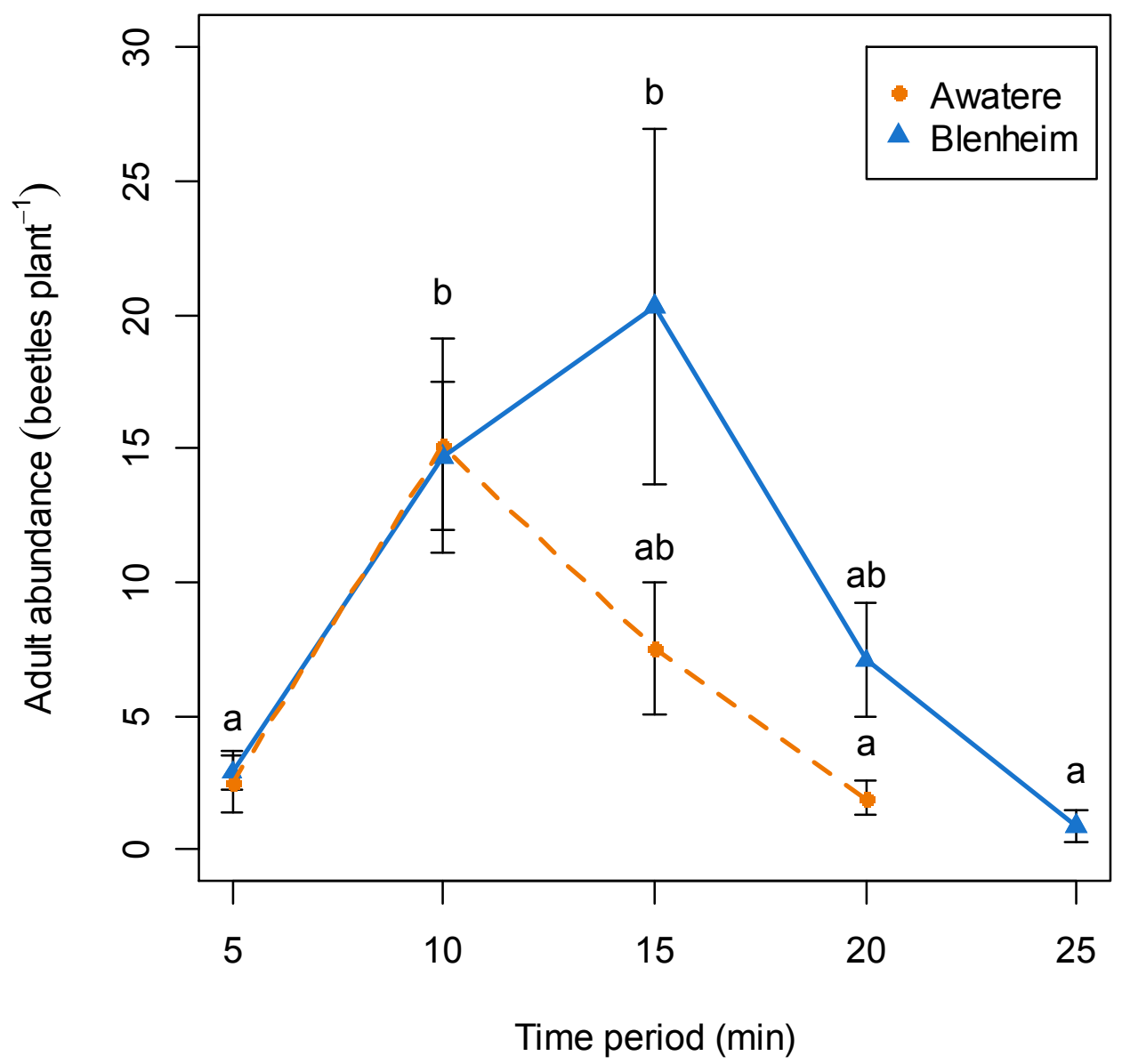

524 Figure 5 Adult abundance during $C$. zealandica daily flight activity at different 5-min time 525 periods, for beetles that landed on a single grape vine plant at the Awatere Valley (dashed line) 526 and Blenheim (solid line) sites. Tukey contrasts are presented as different letters above each dot. 527 Different letters represent significantly differences among the different time periods, but not 528 between studied locations. Error bars are two-standard errors. 